\title{
The Effects of Voluntary Return Programmes on Migration Flows in the Context of the 1973/74 and 2008/09 Economic Crises
}

\section{Piotr Plewa}

\begin{abstract}
The article analyses Spain's voluntary return policies, including the programme instituted specifically to assist migrants affected by the $2008 / 09$ crisis. Voluntary return policies were implemented in Europe in the context of the 1973/4 crisis. Just like the Western European programmes of the 1970s and the 1980s, the current Spanish voluntary return policies also only elicited the cooperation of small numbers of migrants and countries of origin. The article recommends four broader policy measures to tackle the emerging trend whereby a considerable proportion of migrants will stay in Spain rather than repatriate.
\end{abstract}

Keywords: Voluntary returns $\cdot$ Return migration $\cdot$ Spain $\cdot$ Development $\cdot$ Crisis

\section{Introduction}

On 11 November 2008 Spain authorised redundant migrant workers to collect their unemployment benefits in a lump sum and obtain a free return ticket home, allegedly to shield them from the recession. The objective of this study is to assess under which conditions Spain's voluntary return policies (VRPs) have been able to reverse the process of unsustainable, precarious job-based growth while balancing the interests of Spain with those of the countries of origin. Given the sparse take-up of voluntary return programmes in Europe since the mid-1980s, little has been written on this subject over the past two decades. The onset of the $2008 / 09$ crisis has precipitated debates on these policies. This paper aims to inform those debates by reviewing the lessons from the VRP programmes of the 1970s and 1980s and drawing preliminary conclusions from the most recent programme implemented in Spain. The study consists of four parts. It starts with a brief review of the most recent literature on return migration in the context of economic fluctuations. To set the stage for the discussion of the contemporary Spanish voluntary return programmes, the second part briefly sums up various categories of return incentives instituted in the 1970s and 1980s in France, Germany, the Netherlands and Belgium, the four 
countries which instituted voluntary returns as a part of a redefinition of migration policy in the post 1973/4 crisis. It argues that these policies were most successful when they involved cooperation with the countries of origin, development aid and integration of those migrants who decided to stay on.

The third part focuses on the current Spanish voluntary return programmes, particularly the Programa de Abono Anticipado de Prestación a Extranjeros (APRE) - the programme created specifically to assist migrants in the financial crisis. This part discusses the main assumption underlying the current Spanish VRPs, namely that foreign workers and their homelands would acquiesce to voluntary return. It argues that the countries characterised by improving economic, political and social conditions (e.g. Romania) have been more inclined to readmit their migrants, whilst countries in more dire economic, political and social straits (e.g. Morocco) preferred Spain to improve migrants' working and living conditions and encouraged the Diaspora to send remittances and invest at home without giving up their residence abroad. When discussing the positions of the countries of origin, this part makes further references to the VRPs of the 1970s and 1980s, which were also shaped by the attitudes of migrants and their countries of origin.

The fourth part assesses the strengths and weaknesses of Spanish VRPs. It suggests that while VRPs allow migrants to return home in dignity, they cannot address more complex migration policy challenges, particularly: insufficient labour and social integration of those who cannot or do not want to leave Spain; deficiencies in migrants' labour and social integration; persistence of jobs that native populations do not want to perform under the conditions offered; as well as significant economic and social gaps between Spain and migrants' countries of origin. For this reason, when expanding VRPs the Spanish authorities should not delay the efforts to foster (1) the full labour and social integration of migrants already living in Spain; (2) decent working and living conditions for migrants (e.g. through pre-admission rules and post-admission verification); (3) rationalisation, mechanisation, and off-shoring of production in the most labour-intensive sectors; and (4) sustainable development of the countries of origin.

Current voluntary return programmes from the European Union are based on the general EU and specific national legislation on return migration. Delimiting the scope of contemporary analysis to Spain, this article focuses on a study of Spanish legislation, particularly the two decrees which regulated the APRE programme as of May 2010 (RD 4/2008 and RD 1800/2008). The quantitative results of the programme have been provided by the Spanish Ministry of Labour and by the Madrid office of the International Organization for Migration (IOM). The lessons from past programmes in France, Germany, the Netherlands and Belgium are based on a review of the pertinent literature, including the SOPEMI reports on trends in migration in OECD states. Since the goal of the debate on the voluntary return programmes of the 1970s and the 1980s was to identify the key lessons learned rather than provide a full-blown analysis, I limited the analysis of those programmes to a review of the literature and of the data provided in the annual OECD SOPEMI reports.

Voluntary returns from Spain were co-financed by the Spanish Ministry of Labour and Immigration. They were implemented by the IOM and a number of non-govern- 
mental organisations, including but not limited to the Asociación de Cooperación Bolivia España (ACOBE), Asociación Comisión Católica Española de Migración (ACCEM), RESCATE, América - España Solidaridad y Cooperación (AESCO), SpanishEcuadorian Association RUMIÑAHUI, El Movimiento Por la Paz (MPDL), Consorcio de Entidades para la Acción Integral con Migrantes (CEPAIM), and the Spanish Red Cross. To gather data, I conducted telephone interviews with the representatives of the IOM office in Madrid, reviewed documentation from the Ministry of Labour, the IOM and non-governmental organisations (NGO) concerning VRPs, and examined migrants' opinions as expressed in the polls conducted by the ATIME migrant organisation and Spanish social scientists from Colectivo IOE.

One limitation to data gathering was the scarcity of data on migrants' gender, age, civil status, education and employment. Some programme application forms do not require migrants to provide such data. In other cases, the migrants themselves do not provide such information. From the programme administrators' point of view, this data is not as important as the information on the country to which migrants want to return.

\section{Return migration in the context of economic fluctuations}

As of late 2011, a number of authors suggested that return migration in the context of the 2008/09 crisis was not likely to be massive due to migrants being reunited with their families in the host countries (Castles 2011; Dobson et al. 2009), to the homelands' dependence on remittances (Bastia 2011), and to an uncertain reintegration perspective in the countries of origin, as well as to the homelands' ambivalent stance on return migration (Boccagni/Lagomarsino 2011).

In an attempt to provide migrants with greater incentives to return, certain voluntary return policies provided migrants with post-return labour market integration assistance (IOM 2011). However, even the most comprehensive development-fostering return incentives have produced mixed results in the past (Martin 1990). Furthermore, there is little conclusive evidence on whether and how migration affects development. Jones (1998) and de Haas (2005) suggested that migration may exacerbate inequality. Black et al. (2005) argued that it is inequality rather than absolute levels of poverty and deprivation that encourage migration.

Castles (2011) and Dobson et al. (2009) have suggested that demand for migrants is likely to persist because of the shortage of adequately-trained native workers or their unwillingness to work in certain jobs. Arguing that certain voluntary returns, such as those concerning rejected asylum-seekers, are only nominally voluntary, Van Houte and Davids (2008) argued that voluntary return policies may fail to prevent migrants from re-emigrating to the host countries shortly after leaving them.

In order to address the root causes of migration and to render returns sustainable, some scholars and policymakers advocated freer trade, poverty alleviation and other forms of economic aid to the countries of origin. However, de Haas (2007) argued that improved economic and social conditions in migrants' countries of origin are likely to encourage and facilitate migration in the short run. 
For Adepoju et al. migration management should be based on genuinely bilateral or multilateral agreements. Throughout the early 2000 s, migration agreements still aimed to expatriate irregular migrants without much consideration for migrants' homelands. The recent growth of development-linked migration agreements is likely to enhance bilateralism and multilateralism. But it is not only the developed, but also the developing states that could contribute towards better migration management by taking a more coordinated and more decisive role on migration issues (Adepoju et al. 2010: 68). This paper adds to the literature on voluntary returns explaining why a considerable proportion of migrants, particularly those from the countries characterised by significant economic, social and political gaps, could not be expected to return, at least in the short run, and what could be done to address this challenge. Whilst recognising the need for VRPs, the paper calls for the integration of those who will settle, as well as a reduction in the push and pull factors contributing towards the accumulation of migrants in the least stable jobs. As the next section suggests, the host countries were already attempting to create better employment opportunities in migrants' countries of origin in the 1980s, but have gradually learned that some of the migrants would not leave, thereby triggering a need for their integration.

\section{Western European voluntary return programmes in the aftermath of the $1973 / 74$ crisis}

Voluntary return programmes have been implemented in Western Europe since 1977 in the context of the economic and social malaise lingering after the 1973/4 oil crisis as well as rising asylum-seeker flows. France, Germany, Netherlands and Belgium found it politically and administratively difficult to expatriate migrants by force, and therefore decided to make it possible for migrants to depart voluntarily. The programmes differed in their objectives and mechanisms, with some (such as France) offering migrants greater reintegration assistance upon their return home than others (such as Belgium). One way in which Spain could have learned from those programmes was through the experiences of its own nationals. Spanish citizens constituted a significant proportion of the foreign workers within all four countries, particularly in France.

France was the first country to authorise VRPs, and by 2010 had developed the most complex set of such policies in Europe. The French VRP debuted with the 1977 scheme offering 10,000 French Francs to any non-EC foreigner who would renounce any claims to French social security and leave the country. The programme did not attract much interest among the citizens of the most impoverished countries of origin because their governments were not prepared to provide returnees with work and housing. Thus, the French authorities have attempted since 1980 to support the homelands in the reintegration of returning migrants. As of 2009, both documented and undocumented migrants were entitled to some form of VRP consisting of a free return ticket, departure bonuses of up to $€ 2,000$ per adult and $€ 1,000$ per each child, $€ 7,000$ in labour market reinsertion grants and consultative services. 
The German Länder have attempted to administer a VRP since 1975, but it was not until 1983 that the Federal Government authorised immediate repayments of social security and return aid for non-EC migrants willing to depart from Germany. The amounts paid to the beneficiaries of the social security reimbursement programme varied depending on the contributions made by each migrant. Additionally, migrants were able to withdraw their government-subsidised savings before maturity and without penalty, as well as receiving severance pay. They had to leave Germany and could not return there in subsequent years to take up work. The programme did not stipulate that family members had to accompany departing migrants. The return aid was limited to those migrants who had become unemployed or forced to work short hours. Migrants were entitled to DM 10,500 per adult and DM 1,500 per child plus consultative services (OECD 1983: 16; OECD 1984: 35). Unlike the beneficiaries of the social security repayment programme, the beneficiaries of return aid had to leave Germany with their spouses and dependent children, and were not permitted to return to work. The Federal Government did not renew the two programmes, claiming that it was job creation in the countries of origin that should form the basis for a return policy (OECD 1985: 36).

Around 306,000 foreigners were reported to have left Germany during the Repatriation Assistance Act period from November 1983 to September 1984 (OECD 1988: 7), mostly to Turkey. $85 \%$ of applicants for return aid $(14,459$ out of 16,833$)$ and for the social security refund $(120,000$ out of 140,000$)$ were Turkish (OECD 1985: 36). While their return relieved unemployment pressures in Germany, it intensified them in Turkey. Some 250,000 Turks returned from Germany and elsewhere in 1984, notably Libya where Turkish companies were experiencing a $50 \%$ decrease in employment due to falling oil prices (OECD 1986: 22). Unemployment in Turkey was $16.5 \%$ in 1984 . The Turkish government took a number of steps to facilitate the reinsertion of returnees, including customs exemptions, business start-up and housing loans, as well as "catch-up courses" for migrants" children (OECD 1986: 22).

The Dutch considered paying migrants up to 5,000 guilders for returning as early as in 1974, but the investigators concluded that the Dutch Ministry of Development should promote development in the countries of origin regardless of whether their migrants returned or not. Only $10 \%$ of the funds originally destined for voluntary return were allotted for the purpose of voluntary repatriation. Even though most of the returnees whom the programme supported were successful, the Dutch government terminated the programme in 1984. It was argued that the programme's results did not justify its high costs and that the emphasis on return contradicted the spirit of the Netherland's new "minorities policy" (Rogers 1997: 160).

With the introduction of its "minorities policy" in the early 1980s, the Dutch government favoured the settlement of labour migrants. The Scientific Council for Government Policy proposed to structure the policy based on the assumption that most migrants would stay in the Netherlands, and that the efforts should be directed at their integration rather than their return. The Dutch government nevertheless authorised two new return programmes in 1985. These involved no deadlines but prohibited remigration to the Netherlands, which was not well received by migrants and their countries of origin (Rogers 1997: 157). 
The first programme provided migrants with free return tickets and subsistence costs for the first three months in the home country. The second programme enabled migrants aged over 55 (lowered to 50 since October 1987) to return home without losing their unemployment benefits. Returnees under this programme received unemployment benefits corresponding to the cost of living in their homelands until they turned 65 and thus became eligible to receive pensions (Rogers 1997: 158). According to the OECD SOPEMI reports, neither of the two Dutch programmes significantly influenced the return migration figures, particularly among migrants who had reunified with their families in the Netherlands. Settlement was to a large extent facilitated by the Citizenship Act of December 19, 1984 which granted Dutch nationality to 34,600 persons (OECD 1987: 35 ), as well as by the poor employment perspectives at home (Muus 1988: 7).

In 1984, Belgium authorised a modest return assistance programme for humanitarian reasons. Apart from a free return ticket, participating migrants were offered a small amount of cash as well as financial support to offset moving and travel costs. However, out of approximately 200 persons who participated in it, most were asylum-seekers. The authorities therefore created a new programme on 1 August 1985. The programme was available to non-EC nationals who had been unemployed for at least a year. It paid a bonus equal to 312 times the daily unemployment compensation, plus 50,000 and 15,000 Belgian francs to spouses and children, respectively. In exchange for return assistance, migrants had to return with their families, renounce their social and economic rights and privileges in Belgium, and they are not allowed to return to work in Belgium in the future (OECD 1985: 7). In Belgium, like in the Netherlands, settled migrants were able to benefit from reformed naturalisation legislation. The new law was a major reason for the $5.7 \%$ drop in the migrant population in Belgium in 1985.It most likely also led to the poor VRP application rate. Only 594 people, mostly Turks, decided to benefit from the programme until it was terminated in July 1989 (OECD 1987: 21; OECD 1990: 16).

Thirty-five years after the authorisation of first VRP in Europe, there is no evidence to what extent VRPs stimulate returns and to what degree they subsidise the returns of those who were going to return anyway. The numbers of migrants who benefitted from these schemes were often smaller than expected by the receiving host countries, and larger than considered sustainable by the homelands. As migration flows linked receiving countries to increasingly more economically, politically and culturally distant countries of origin, providing migrants with the opportunities for a sustainable return became more difficult.

One major difference between the contemporary Spanish and the four historical Western European programmes was that historical programmes were conceived between three and ten years after the peak of the economic crisis, while the contemporary Spanish programme was instituted during the recession. The former programmes addressed migrants who had already had time to grasp the new economic reality, whilst the contemporary programme addressed migrants who were not sure what the future would bring. Another major difference between the two generations of programmes stemmed from globalisation. Transportation costs had become lower by the late 2000s, making it possible for the host states to open the 
programme to a larger number of migrants, but also making it easier for migrants to re-emigrate if they found that the conditions at home were not what they had expected them to be. The availability of cheap communication infrastructures also allowed programme administrators and migrants to gather relatively precise information regarding the conditions awaiting them upon return. Last but not least, the programmes of the 2000s benefitted from the financial support of the European Union and the logistical support of the International Organization for Migration and of plenty of NGOs, both in Europe and in migrants' countries of origin. While VRPs were a novelty in the context of the 1973/4 crisis, and could be regarded with suspicion in the context of the 2008/09 crisis, they were known, enjoyed a larger financial and administrative infrastructure, and thus had legitimacy. In short, one would expect the VRPs of the 2000s to have been much more successful than those of the 1970s and the 1980s. The following sections will attempt to shed more light on whether they have done so or not.

\section{Spain's 2009-2010 voluntary return programmes}

Spain was among the fastest-growing immigration countries in Europe throughout the 2000s. The immigrant population in Spain grew by an average of 500,000 people a year between 1999 and 2008 (Ferrero-Turrión 2010: 96). At the height of the crisis, in 2009 , the foreign-born population constituted $14.3 \%$ of the total population in Spain (OECD 2011: 325). However, foreigners were also most affected by the crisis.

In the third trimester of 2011 the unemployment rate in Spain was $21.52 \%$ (32.72 among foreigners and 19.50 among Spanish citizens) (INE 2011: 1-2). Moroccans $(22.08 \%)$, Romanians (15.71\%), Ecuadorians $(9.93 \%)$ and Colombians $(6.05 \%)$ constituted over half of all foreign workers drawing unemployment benefits (INEM 2011: 65). Most of them had lost employment in construction, services and agriculture, the three sectors worst affected by the crisis. Immigration to Spain had been closely tied to these sectors, and to construction in particular. Hence their decline translated immediately into heightened unemployment among foreign workers.

The Spanish government had expected migrants who had not yet come to Spain to postpone migration plans and migrants who had already arrived in Spain to repatriate. As far as the new flows are concerned, the economic crisis marked a decline in migration flows across all categories of migrants. Between $2008(690,000)$ and 2009 $(470,000)$, migration flows to Spain declined by over $30 \%$. The inflows declined across all major categories: The number of new residence visas issued decreased from 290,000 in 2008 to 160,000 in 2009; the number of foreign-born seasonal workers recruited in the countries of origin fell from 42,000 in 2008 to 6,000 in 2009; the number of asylum applicants decreased by one-third to about 3,000; the number of irregular migrants apprehended at Spain's maritime borders decreased from 13,000 in 2008 to only 9,000 in 2009 and less than 200 in 2010 (OECD 2011: 324). The second expectation - concerning the voluntary repatriation of migrants already present in Spain - is discussed in detail in the sections that follow. 


\subsection{The Three Major Categories of Spain's VRPs}

Since December 2010, migrants in Spain have been able to apply to one of three categories of voluntary return programmes: (1) humanitarian-based PREVIE, PREVICAT, PREVICAM, PREVIVAL; ${ }^{1}$ (2) unemployment-based (APRE); and (3) investmentbased. While co-designed and co-financed by the Spanish Ministry of Labour, the programmes were managed by the IOM and approved humanitarian or migrant organisations. $^{2}$

The humanitarian and investment-based VRPs targeted both legal and illegal migrants, as well as unprocessed asylum-seekers. In order to qualify, those applying for the humanitarian programme had to prove that they could no longer support themselves in Spain. By contrast, those applying for the investment-based programme had to have a post-return investment plan. The humanitarian and investment-based VRPs targeted both European Union (EU) and non-EU citizens. The unemployment-based VRP (APRE) targeted those legal migrants who wished to collect the lump sum of their unemployment benefits immediately. It was opened up to citizens of those non-EU countries which had concluded social security agreements with Spain.

The beneficiaries of all programmes were entitled to free transportation home. The families of the beneficiaries of the humanitarian-based and unemploymentbased programmes had their travel costs covered as well. Each programme provided returnees with $€ 50$ in pocket money (per returnee, up to $€ 400$ ). The humanitarian and investment-based VRPs offered $€ 400$ in return grants per person, up to $€ 1,600$ per family or group of investors. APRE returnees were excluded from departure bonuses as it was assumed that their unemployment benefits would be greater. The investment-based programme additionally granted a project-specific development grant of $€ 1,500$, up to $€ 5,000$ for projects implemented by several entrepreneurs.

\subsection{APRE: the special VRP to boost returns in the context of the $2008 / 2010$ crisis}

The APRE programme was advertised in all of Spain's employment services offices, where the applications had to be completed. Candidates had to be citizens of a country which: (1) had a social security agreement with Spain and (2) was not a member of the EU, the European Economic Area or Switzerland. The first condition aimed to ensure that workers would be able to collect the departure bonuses once

1 The four programmes correspond to the geographical scope of their implementation. PREVIE (Programa de Retorno Voluntario de Inmigrantes desde España) has been implemented in all of Spain, PREVICAT (Programa de Retorno Voluntario de Inmigrantes desde Cataluña) in Cataluña, PREVICAM (Programa de Retorno Voluntario de Inmigrantes de la Comunidad de Madrid) in Madrid, and PREVIVAL (Programa de Retorno Voluntario de Inmigrantes desde Valencia) in Valencia.

Personal communication with Paloma Sevillano, IOM Madrid, 18 November 2010. 
they returned home. The second condition aimed to prevent workers from returning to Spain after having collected the bonus. According to these two principles, the VRP applied to citizens of Argentina, Andorra, Australia, Brazil, Canada, Chile, Colombia, the Dominican Republic, Ecuador, the United States, the Philippines, Morocco, Mexico, Paraguay, Peru, Russia, Tunisia, Ukraine, Uruguay and Venezuela (MTAS 2010).

Migrants who wished to participate in the APRE programme had to be eligible for unemployment benefits. Migrants could sign up for the programme at any point in time while they were receiving such benefits, but the longer they waited the smaller the voluntary return benefits they were going to obtain. When unemployed migrants exhaust their unemployment benefits, they become illegible for the programme. Thus, while the APRE VRP was cost-effective, it limited itself to assisting those migrants who were likely to leave Spain from the very outset. With the amount of benefits decreasing over time, the programme was ill-prepared to attract undecided migrants, not to mention those who regarded repatriation from Spain as the last resort.

Even those migrants who are a priori open to the idea of returning may find it difficult to depart right away because of the time involved in paying off loans; selling property and equipment; being released from house rent contracts; as well as finding new housing, jobs and schools for children in the country of origin. The single workers with families back home are least constrained by those pre-departure prerequisites, but entire families require both time and assistance to make return decisions, particularly if one spouse continues to work, children are attending school and family members back in the countries of origin cannot help in finding jobs and housing.

The Spanish VRPs provided relatively weak return incentives for family members. Apart from free transportation, similar schemes operating during the crisis in France paid $€ 3,500$ to a married couple and $€ 1,000$ per child (up to three children and $€ 500$ for any additional child). The Czech crisis VRP paid $€ 500$ to the spouse and $€ 250$ per child. The Spanish programme provided $€ 400$ per spouse. Spanish returnees also received $€ 50$ in pocket money each (up to $€ 400$ for a family) (MTAS 2010).

Even the countries which paid bonuses to returning family members found it challenging to convince migrants to leave. Among other things, migrants could have been preoccupied as to the extent to which their return would affect their children's ability to succeed in future. Thus, some migrants just stayed to give their children the opportunity to start their lives from a better position than their parents did. Unlike some German Länder in the 1970s and 1980s, Spain did not prepare the children of migrant workers for their return home. Educating migrant children with Spanish children was expected to foster their integration, which was considered more important than preparing them for a possible return. In order to provide migrant children with educational opportunities in the countries of origin equivalent to those which were afforded to them in Spain, returning migrants would need to send their children to costly private schools. This was not an option in rural areas of most of the countries of origin. According to Laura Tedesco, an Argentinean political sci- 
entist, many Ecuadorian migrants to Spain originate from rural areas which lack basic services such as free healthcare and education. Such services are available to migrants who decide to stay in Spain (Moffett/House 2010).

Once migrants committed themselves to voluntary return, they received one way tickets, $€ 50$ per person for travel to the port of departure as well as $40 \%$ of the unclaimed unemployment benefits available to them. In exchange, they had to leave Spain within 30 days. They could change their mind before receiving the $40 \%$ payment, but not after. Once in the country of origin, the returnees must report in person to the Spanish embassy or consulate to surrender any documents necessary to live and work in Spain (work and residence permits, identity card, social security card, health care card, etc.) to the Spanish diplomatic mission abroad in order to receive the remaining $60 \%$ of their unemployment bonus.

Sending migrants home requires considerable psychological, administrative and financial assistance. Since the 1980s, the French government has provided returning migrants with pre-departure counselling, professional training and assistance in selling property. The French encouraged the countries of origin to reduce duties on imported goods and even provided migrants with funds to purchase work tools as well as subsidising their transportation. The Spanish authorities did not provide migrants with comprehensive counselling or administrative or financial assistance, thereby making it more difficult for migrants to leave and for the countries of origin to receive them. According to the Ecuadorian Migration Office, migrants who were entitled to smaller return benefits found it difficult to afford to return home because the money spent on transporting belongings decreased the ability of returned migrants to invest at home. To make up for this problem, the Ecuadorian Migration Office authorised duty exemptions for returning migrants. One of the main goals of such exemptions was to allow migrants to bring all the tools necessary to start up in business upon their return (SENAMI 2012a).

Unemployed migrant workers were eligible for the same retraining packages as unemployed Spanish workers. However, the Spanish government did not offer specific retraining services to migrants participating in APRE in their home countries. France has organised labour market reinsertion programmes to the home countries since 1984. At first the programmes aimed to lure migrant workers to depart and accepted almost any post-return projects that migrants proposed. But with time, and perhaps in response to illegal returns to France of those who failed to establish a sustainable business in the countries of origin, the French government began to pay more attention to the quality of pre- as well as post-departure training so as to maximise the sustainability of migrants' return. By 2009, France's migrants were eligible for up to $€ 7,000$ in seed money, project planning and project follow up assistance to become self-employed upon their return to their home countries.

It is surprising that the Spanish government expected the countries of origin to willingly accept their migrants given that Spain herself was reluctant to readmit its own nationals from Western Europe in the 1980s. A magazine for Spaniards abroad published by the Spanish government emphasised: "Many (emigrants), even if they wish it, cannot return to Spain right now, given the economic and social crisis situa- 
tion experienced by the Spanish economy" (Struckow y Gonzalez 1986: 27 in Rogers 1997: 158).

\subsection{The non-unanimous position of the countries of origin}

The governments of economically, politically and socially stable countries favoured the permanent return of their migrant workers. By contrast, the governments of the countries which were yet to achieve such stability generally preferred migrants to send remittances and invest at home, while residing abroad (Lahlou 2006: 14). These governments would not reject any migrant returning voluntarily. However, they did not actively encourage migrants to return. From the Spanish perspective, it was not the citizens of the more highly developed, but rather of the less-developed countries which needed to depart first. Romania demonstrated considerable interest in expanding the programme to its citizens because it viewed the EU investment funds as much more valuable than remittances. By contrast, with the exception of some basic return incentives such as exemptions from import duties, Morocco did not appear very supportive of the programme. Morocco was more interested in the regularisation and integration of its citizens abroad than in their permanent return (Lahlou 2006: 13-14; Sorensen 2004: 8). Experiments with organised permanent return to Morocco have not been successful (Sorensen 2004: 9). By 2010, $9.3 \%$ of Moroccan population resided abroad remitting 6,447 million US dollars annually. With the economic crisis having a minor negative impact on remittance flows to Morocco (Table 1), Moroccan authorities would have undercut an important source of income if their emigrants were to come home for extended periods of time. However, Moroccan authorities' interest in using remittances as a tool for the country's development may enhance returns if these were to be based on Diaspora investments rather than extended or permanent returns, as the Spanish government had hoped.

The beneficiaries of the APRE programme were prohibited from re-entering Spain for three years following departure. Migrants suspected that the three-year ban aimed to make them settle in their countries of origin because of the high costs of moving back and forth. The lessons from the French 1977 programme revealed that Portuguese and Spaniards who had left for home on voluntary return bonuses had returned to France illegally prior to the 1982 legalisation (Weil 1991: 327). Many migrants wished that they could have a trial period to return to Spain at any time if the conditions at home were not propitious for resettlement.

Tab. 1: Remittances to Morocco, 2003-2010 (in millions of US dollars)

\begin{tabular}{lllllllll}
\hline Year & 2003 & 2004 & 2005 & 2006 & 2007 & 2008 & 2009 & 2010 \\
Remittances & 3,614 & 4,221 & 4,590 & 5,451 & 6,730 & 6,895 & 6,271 & 6,447 \\
\hline
\end{tabular}

Source: Own calculation, based on Ratha/Mohapatra/Silwal 2011. 
The ban on returns to Spain was one reason why the APRE programme did not apply to EU citizens. With no internal controls and the EU right to reside anywhere in the EU, it would be impossible to extend the programme for instance to Romanians. The Romanian government was nonetheless interested in extending voluntary return to its citizens because emigration had reduced its ability to attract foreign investment and use post-accession EU funds. The Romanian government did not have enough funds to motivate its citizens to return, and counted on the support through the Spanish VRP.

While the Romanian government viewed the economic crisis in Spain as an opportunity for national development, Morocco and Ecuador appeared to know the limits of their capacity to integrate returnees. They faced a dilemma between accepting the returnees or acquiescing to their downward labour mobility from yearlong or full-time jobs to seasonal jobs and part-time jobs. Since the Spanish VRP did not include any training or job-creation provisions, the non-EU countries expected the programme to increase unemployment pressures and interrupt the flow of remittances.

The non-EU countries of origin were interested in the social and economic wellbeing of their citizens. Whilst they supported the spontaneous return of their citizens, and even co-financed it through customs exemptions and other minor postreturn assistance measures, their resources for reception were limited, particularly if migrants were to come home en masse and all at the same time. The Ecuadorian President Rafael Correa acknowledged that Ecuador was not able to assist all 50,000 unemployed Ecuadorians if they were to return from Spain (Gallego-Díaz/Creamer 2009). The onset of the economic crisis further reduced their capacities for reception, not only because they were affected by the crisis too, but also because Spain was not the only country which attempted to expatriate their nationals. From the Spanish perspective, if all of the Moroccan, Ecuadorian and Colombian workers who were eligible for unemployment benefits were to depart, their countries of origin would need to receive around $36,000,21,000$ and 11,000 returnees, respectively. However, from the Moroccan, Ecuadorian and Colombian perspective, the numbers of returnees were significantly larger given the simultaneous voluntary return programme in France as well as spontaneous and forced returns of their Diasporas from other countries. The cautious stand on return migration among the countries of origin predated the crisis. Had Spanish officials taken it into consideration, they would have been able to build a policy based on more realistic assumptions. But they had not. Hence a perception of uncooperativeness on the part of the countries of origin arose when the programme started.

According to the Ecuadorian Migration Office (SENAMI - Secretaría Nacional del Migrante), voluntary return policies should be based on genuine cooperation with the host states, should allow migrants to maintain their residence in Spain while strengthening links with Ecuador through remittance transfers and investment, should allow them to circulate back and forth between Spain and Ecuador; and if they decide to settle back in Ecuador, they should be offered enough time, financial and professional support to ensure that they would be financially and socially stable enough not to want to re-emigrate to Spain (SENAMI 2009). 
Despite divergent conceptualisations of VRP, Ecuador developed the most comprehensive set of reception policies, as compared to the two other countries with the largest number of migrants eligible to return (Morocco and Colombia). The Ecuadorian "Welcome Home" policy consisted of duty exemptions on household and professional equipment brought from abroad, housing loans and business start-up funds. Ecuadorian migrants who had lived abroad for at least one year could be exempt from duty on household appliances, tools and machinery valued up to $\$ 4,000$. Additionally, they could import one car worth up to $\$ 15,000$ (SENAMI 2012a). Migrants who were going to return anyway welcomed the duty exemption, but those who were undecided considered it too modest given the high shipping costs and other fees involved. Ecuadorian returnees who did not own a house in Ecuador could also apply for a housing loan of up to $\$ 50,000$. Some migrants would have preferred the loan not to tie them to government-approved construction companies, as some regarded these companies as slow and considered that they sold houses at inflated costs (Migrante Ecuatoriano 2009). Migrants could apply for a housing Ioan prior to arrival in Ecuador. It remains to be seen whether having secured a loan, migrants would arrive home or would wait until the house was almost complete, as well as whether they would prefer to live in that house or consider it as an additional source of income while continuing to reside in Spain.

Since January 2007, returning migrants who have resided abroad for at least one year have also been able to compete for investment grants. This initiative inspired the greatest optimism among Ecuadorian migrants abroad. The grant aimed to help Ecuadorians develop a new investment or support an existing one. Ideally, investment would concern agriculture, tourism, transportation and services, as well as being innovative and having a multiplier effect. The funds were expected to be complementary, thereby favouring migrants who had returned home with substantial savings (SENAMI 2011).

In 2011 , the grant amounted to up to $\$ 15,000$ or $\$ 50,000$, depending on whether the project had an individual/family or community character (SENAMI 2011). Many projects were used to support farms and grocery stores. Given the potential for the "overcrowding" of the same type of business initiative, migrants and the grant selection committee were concerned about the originality and thus the sustainability of the projects. Migrants felt that investment-based programmes needed to be coupled with comprehensive project development support both at the project planning and implementation stages (SENAMI 2011).

To assist migrants in making a return decision, the Ecuadorian government provided its cultural institutes in Spain - Casas Ecuatorianas - with the financial and administrative capacity to keep the Diaspora informed about what they could expect in Ecuador on their return (SENAMI 2012b). The Casas facilitated contact between migrants and potential employers in Ecuador, provided information on educational reinsertion of migrant children, and assisted migrant families with some administrative tasks associated with departure. The staff at the Casas attempted to offer migrants the most realistic information necessary to make a decision. They did not aim to convince migrants to come back if the conditions for their return (migrants' post-return plans, preparation, economic conditions in the place of return, etc.) sug- 
gested that they might be worse off in Ecuador than in Spain. The Casas offered migrants a number of social and professional services aimed at maintaining a link between migrants and Ecuador, regardless of whether and when they might opt to return. Citizens of other countries could also benefit from the advice necessary to make an objective decision regarding whether to return or stay. These consultation services were usually provided by migrant organisations, NGOs, religious leaders and the IOM.

Colombia had attempted to readmit its workers in the past and scrutinised similar efforts made by other Latin American countries. In an attempt to enable its citizens to continue their business activities upon their return, Colombia had by the 1970s already experimented with duty exemptions incentives similar to those implemented by Ecuador after 2008. The duty incentives did not precipitate significant returns to Colombia because migrants were more concerned with political and economic stability at home than with the cost of return. The success of return migration to Chile after 1973 demonstrated that political stability can spur return migration by itself (Rogers 1981: 350). Given the lessons of the past, and the awareness of its inability to boost migrants' confidence in economic and political stability, Colombia both facilitated returns and tried to improve migrants' living and working conditions in Spain.

By 2008, the Moroccan Diaspora abroad was estimated at 3 million. In most cases, Moroccan migrants maintained close social, cultural and economic ties with their country of origin (IOM 2010c). Reliant on remittances, and aware of the high costs associated with effective voluntary return programmes, the Moroccan government prioritised the amelioration of migrants' working and living conditions over permanent returns. Rabat held that Moroccans should have the right to work and live abroad if it is to help their families in Morocco and, if their families joined them abroad, they should have the right to invest in Morocco without compromising their legal status in the countries of origin. The preference for gradual, and not necessarily permanent, return stemmed not only from Morocco's own experience, but also from the lessons drawn from the Franco-Algerian return experience. When the French authorities authorised the 1977 voluntary return programme, the Algerian authorities did not look forward to grappling with the secondary labour, social and political integration of its long-term emigrants, who overall had spent more time abroad than in Algeria. It feared any returns that were not genuine (Miller 1979: 334) or small enough to integrate.

Many Algerians who returned home in the aftermath of the 1973/74 oil crisis did so because they had planned to return anyway. In most cases, the undecided Algerians returned only when they were guaranteed jobs and housing (Adler 1976: 42 in Rogers 1981: 350). Similar to Algeria, Morocco was only able to provide jobs and housing over an extended period of time and to a limited number of returnees.

Remittances to Morocco grew from DHS 20 billion in 1998 to DHS 57 billion in 2007. Since 2005 they have represented around $8 \%$ of GDP, $290 \%$ of foreign direct investment, $700 \%$ of development aid and the most important source of foreign currency. They accounted for Morocco's positive balance of payments (MAEC 2009). Until roughly 2005, most Moroccans had invested in real estate. However, since the 
Moroccan real estate market became saturated, migrants started to purchase real estate in their host countries, particularly in those cases where their spouses had arrived and their children had been born abroad (Hamdouch 2005: 71).

According to Youssef Amrani, the director of bilateral relations at the Moroccan Ministry of Foreign Affairs, migrants should be able to freely circulate back and forth between Morocco and the host country, so as to allow them and Morocco seamless re-adaptation in the labour market and society (Marrakech Info 2008). In this respect, Moroccan authorities, just like migrants, opposed the three-year prohibition to return to Spain.

Apart from free transportation and a departure bonus, Moroccan migrants returning from Spain could only count on the Moukawalati Project start-up loan provided by the Moroccan employment office (ANAPEC). The loan was available to educated Moroccans who could cover $90 \%$ of the project costs themselves. It was far less attractive than project start-up grants available to Moroccan returnees from France because those returning from France could obtain up to $€ 7,000$ in project start-up grants distributed by the French ANAEM office. Given that the French voluntary return programme did not make eligibility conditional on legal status, and the paucity of Spanish-French border controls, Spanish Moroccans with families in France may be able to increase their return benefits by temporarily moving to France so as to return with the assistance of the French rather than Spanish VRP.

Having grappled with the same challenge since 1977, by the early 2000s France began to redefine its voluntary return policy to do better justice to the interests of the countries of origin. The current French VRP encourages legal migrants to invest in their countries of origin while maintaining legal status in France with the so-called "circulatory visa" (visa de circulation), so that they could come back to France whenever they wish, or, if they find it more beneficial, run a business in the country of origin from France (France 2005: 57). Regardless of legal status, French migrants were allotted up to $€ 7,000$ in investment start-up funds, and holders of permanent residence permits could apply for an additional $€ 1,067$ to $€ 1,220$ to research the feasibility of the the business plans they intended to carry out upon return. It may be too early to judge to what extent the French VRP would translate into increased departures. However, having attempted to make the programme more bilateral, the French programme seems to have been more popular among migrants, their countries of origin and French society than the unilateral Spanish programme.

Studies of Turkish returnees from Germany in the 1980s showed that at most $50 \%$ of the respondents in a given sample had created or found employment following their return; some studies found considerably lower proportions (Hönekopp 1987 and Akcayli/Sen 1987 in Rogers 1997: 162). The spokespeople for home country governments warned migrants not to make return decisions hastily. Migrants were implored to plan their return carefully, to weigh carefully what they were giving up in terms of social benefits and entitlements by leaving the host country, and to know precisely whether they could buy into pension schemes in the home countries (Rogers 1997: 162).

A 1987 report on the second generation in Germany and Turkey advised migrants not to return: "Return incentive policies are against Turkey's interests. Return 
is also against the interests of the returnees. In Turkey there are no institutions for reintegration that could assist returns. The bilateral agreements between Turkey and the Federal Republic of Germany do not work well. So far no reintegration assistance project has come to fruition. Therefore the future of the second generation of Turkish migrants ... remains in the Federal Republic" (Akcayli 1987: 21 in Rogers 1997: 158).

\subsection{Migrants and employers: scepticism about permanent return}

Ecuadorian (Rumiñahui) and Moroccan (ATIME) organisations were sceptical whether the Spanish VRP would be able to attract many Ecuadorians and Moroccans given what it offered and what it expected migrants to give up. They held that the bonus should be larger and that there should not be a prohibition to re-enter Spain. They emphasised that the countries of origin were not prepared to offer returning migrants sustainable sources of income and housing.

According to Dora Aguirre, the president of Rumiñahui, even those migrants who collected up to $€ 7,000$ in unemployment benefits would still find it difficult to leave Spain (El Mundo 2008b). Whilst most Ecuadorians had originally planned to return home, their attitudes have changed the longer they stayed in Spain. In this respect, the post-Cold War migrants to Spain did not differ much from post-War migrants to France or Germany: They underwent what $R$. Böhning (1984: 79-86) described as maturing of migration streams, and required a more complex policy built on the assumption that some would leave whilst others would not; facilitating their reintegration in the homelands as well as their full integration in the host society.

In a survey conducted by Colectivo IOE prior to the financial crisis, Ecuadorian migrants explained the reasons motivating their prolonged stay in Spain and their return home (Fig. 1 and 2). Three-quarters of Ecuadorians decided to prolong their stay in Spain because they believed that they could secure better working and living conditions there than in their homelands ( $26 \%$ ); because their family members had moved to Spain ( $23 \%)$; because they had taken initial steps towards settlement (16\%); or because they hoped for social and labour mobility in Spain (10 \%) (Fig. 1). By contrast, the three main reasons why the respondents expressed an interest in returning to Ecuador were family-related (41\%), homesickness $(26 \%)$ and dissatisfaction with their lives in Spain (15\%) (Fig. 2).

Despite the Ecuadorian government's efforts to facilitate return migration, Ecuadorian migrants appeared to doubt that employment opportunities at home would improve in the near future. Even if Ecuador could attract foreign investment the way Mexico did, it would first occur in areas with decent infrastructure and only after that in the rural and geographically-isolated areas from which many migrants came. Even if maquiladoras (foreign capital supported factories) sprung up in Ecuador, work on an assembly line would mean downward labour mobility for many Ecuadorians who had worked in the Spanish service sector. The investment grant constituted an important incentive to return, but it required own capital and careful planning to overcome a whole range of administrative and practical challenges to investment in Ecuador's less developed areas. 
Fig. 1: Rationale behind prolonged stay in Spain

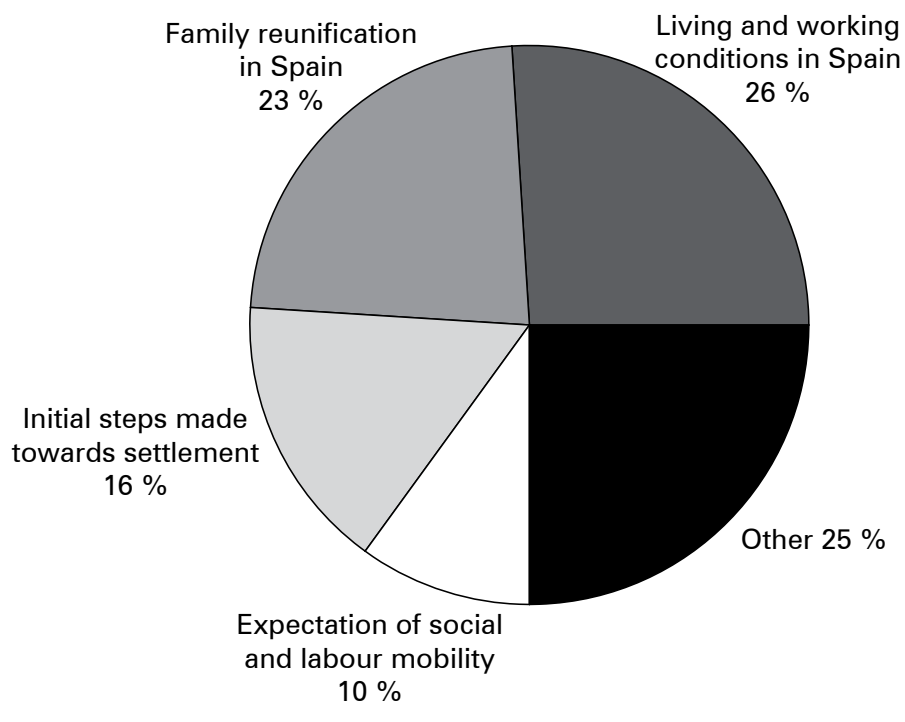

Source: Own design based on data from Colectivo IOE 2007: 156.

Fig. 2: Rationale behind return to Ecuador

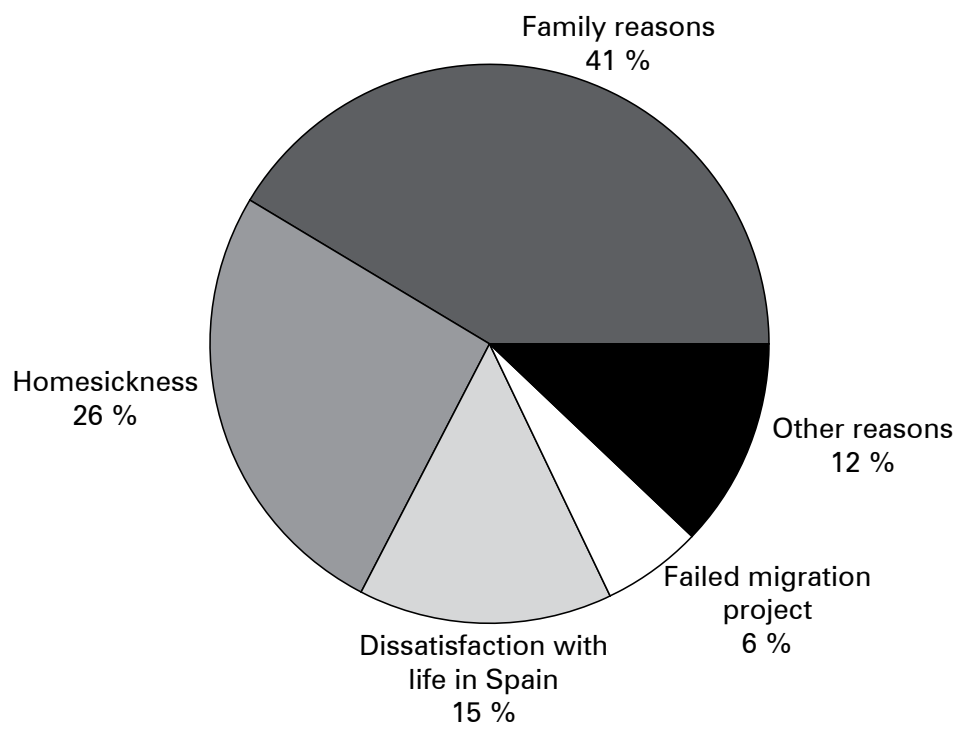

Source: Own design based on data from Colectivo IOE 2007: 157. 
Even when unemployed, some migrants could be better off in Spain than in their countries of origin. Spanish law provides migrants with services such as free health care, free education for children and re-qualification programmes, regardless of legal and employment status. Furthermore, the crisis had a milder effect on the demand for workers in agriculture, services and tourism, and in the informal economy. Thus, as long as foreign migrants were willing to accept difficult work for low pay, they had an alternative. The longer migrants stayed in Spain, the more rights they were afforded. The voluntary return programme promised that after a three-year stay abroad, migrants would be able to claim the period of legal residence in Spain to adjust their status and e.g. migrants who had earned permanent status would not be negatively affected. However, to return, migrants would have to apply for new visas (SEPE 2012).

The Minister of Labour considered VRP to be consistent with the Spanish policy on labour migration, as it enforced the principle that migrant workers should be admitted in view of the ability of the Spanish labour market and society to integrate them. The Minister explained that the new economic scenario, characterised by significant growth in unemployment, required that the national labour reserve, be it Spanish or legally-resident foreign nationals, be given priority in employment. Only when these sources are exhausted should employers be permitted to bring workers from outside of Spain (MTAS 2008b).

Like migrant organisations, labour unions also feared that immigrants had not earned enough in unemployment benefits and that the three-year re-entry ban would discourage even those with the most savings from participating in the VRP. Furthermore, those who had saved more substantial amounts should not be encouraged to leave because they had probably integrated well into the Spanish economy and society (De/ Barrio 2008). Both labour unions and migrant organisations also agreed that the Spanish government should encourage investment in migrants' homelands to provide migrants with durable employment opportunities following their return. Alternatively - the labour unions claimed - the Spanish government should facilitate migrants' settlement given how much they had contributed to the Spanish economic boom.

Employers who depended on foreign workers preferred the government not to incentivise migrants to leave or curb new admissions. They claimed that any unexpected decrease in labour supply would penalise Spanish businesses without necessarily helping the Spanish unemployed. Farmers and growers argued that, they continued to find it difficult to attract Spanish workers despite the economic crisis (El Mundo 2008a).

\subsection{Initial results: weak interest except among Latin Americans}

When the Ministry of Labour launched the APRE programme on 12 November 2008, there were over 138 thousand unemployed foreigners in the country who met the programme criteria and could theoretically repatriate. However, the Ministry did not take into consideration the attitudes of employers, migrants and the countries of origin. Even if those attitudes had been taken into consideration, it would have been 
difficult to predict the number of returnees as the attitudes of migrants, employers and the countries of origin have been changing.

According to the Ministry of Labour's calculations, 2,191 persons (including family members) were subsidised to leave through the humanitarian-based VRPs, 2,171 through APRE and 99 through the investment-based VRPs between January and September 2010. The pace of return appeared to slow down in 2010 as compared to 2009, when 4,022 persons left Spain through humanitarian-based VRPs and 4,365 through APRE (MTAS 2010).

Based on the Ministry of Labour's 2009-2010 data, some $90 \%$ of all those who repatriated through the humanitarian VRP returned to Latin America, primarily Bolivia $(24 \%, 1,520)$, Argentina $(15 \%, 941)$ and Brazil $(12.6 \%, 788)$. Romanians constituted the largest non-American nationality $(1.8 \%$, 115) (MTAS 2010). Latin Americans also accounted for the largest group in the investment and unemployment-based VRPs. Bolivians accounted for a quarter of all returnees for investment, but none in the APRE programme, due to their inability to meet APRE's conditions (legal status and entitlement to unemployment benefits).

According to the Ministry of Labour, by 27 May 2010 - nineteen months into the programme - 7,087 persons had applied for APRE (Table 2). Roughly three-quarters were approved and returned home; 1,691 (23\%) were rejected due to incomplete or erroneous applications or awaiting decision. According to the Spanish Employment Services, the medium voluntary return bonus amounted to $€ 9035$, 81 per migrant as of 3 June 2009, indicating that those migrants who used the programme applied soon after becoming unemployed.

The Ministry of Labour's data shows that no Moroccan or other African had benefited from the unemployment-based VRP-APRE until 27 May 2010. Over $99 \%$ of returnees originated from Latin America, principally Ecuador, which accounted for $45 \%$ of returnees (Table 2). It appears that socio-economic and political conditions

Tab. 2: Provisional results of the Ministry of Labour's (APRE) Programme 11 November 2008-27 May 2010

\begin{tabular}{lcc}
\hline Country & Applications filed & Applications approved \\
\hline Ecuador & 3,251 & 2,509 \\
Colombia & 1,315 & 982 \\
Argentina & 810 & 609 \\
Peru & 483 & 365 \\
Brazil & 440 & 325 \\
Uruguay & 311 & 251 \\
Chile & 358 & 268 \\
Other & 119 & 87 \\
Total & 7,087 & 5,396 \\
\hline
\end{tabular}

Source: Personal communication with Adela Morales del Olmo, Ministry of Labour, 27 May 2010. 
in the country of origin and the degree of cooperation between the country of origin and Spain are among the factors explaining the divergent trend between returns to Morocco and Ecuador. The onset of political instability in Northern Africa, coupled with the recovery of the Spanish economy by the spring of 2011, made further returns to Africa even more unlikely. Legal status did not seem to play a significant role because there were more unemployed Moroccan workers in Spain entitled to unemployment benefits than Ecuadorians and other Latin Americans.

The numbers of those availing themselves of an IOM-managed voluntary return from Spain grew rapidly until the onset of the crisis, but appeared to slow down afterwards, as if migrants expected it to be more difficult to return to Spain in the future. However, the decrease in returns could have also been precipitated by the discontinuation of the IOM-managed voluntary returns from Madrid and Catalonia (Table 3) due to budgetary constraints as well as reduced admissions (IOM 2010d).

Tab. 3: Number of IOM-assisted returnees, by programme, 2003-June 2010

\begin{tabular}{lcccccrrrr}
\hline & 2003 & 2004 & 2005 & 2006 & 2007 & 2008 & 2009 & 2010 & Total \\
\hline APRE & - & - & - & - & - & 110 & 199 & 142 & 451 \\
PREVIE & 199 & 393 & 392 & 397 & 531 & 1,076 & 591 & 271 & 3,850 \\
PREVICAM & - & - & - & 60 & 573 & 210 & 0 & 0 & 843 \\
PREVICAT & - & - & - & 85 & 142 & 179 & 361 & 169 & 936 \\
PREVIVAL & - & - & - & - & 22 & 17 & 0 & 0 & 39 \\
Total & 199 & 393 & 392 & 542 & 1,268 & 1,592 & 1,151 & 582 & 6,119 \\
\hline
\end{tabular}

Source: Personal communication with Paloma Sevillano, IOM Madrid, 18 November 2010.

The number of migrants who returned home with the assistance of the Spanish IOM grew over the years until 2008. It declined afterwards due to a lack of funds (Table 4). All in all, 5,537 people have benefited from IOM voluntary return assistance since the programme's inception in 2003, particularly Bolivians who accounted for over a quarter of all returnees. By contrast, no Moroccans returned home throughout the entire programme duration. Unlike Ecuador, Bolivia did not implement any special incentives for the migrants to return home and economic conditions in Bolivia remained difficult, suggesting that those Bolivians who returned could have been in genuinely precarious conditions while in Spain. High return rates among Brazilians and Argentineans could be explained by the relatively good economic, social and political conditions at home.

When compared with the overall figures on migration outflows, voluntary returns were relatively modest, this being due to a large extent to departures by migrants who could not or did not want to avail themselves of subsidised return (Table 5). Over 288,000 departures were registered in Spain in 2009. The statistics on migration outflows must however be treated with a certain caution as they also include 
Tab. 4: The principal ten nationalities of migrants who returned with IOM assistance, 2003-2009 (APRE, PREVIE, PREVICAM, PREVICAT, PREVIVAL)

\begin{tabular}{lrrrrrrrr}
\hline Country & 2003 & 2004 & 2005 & 2006 & 2007 & 2008 & 2009 & Total \\
\hline Bolivia & 12 & 54 & 77 & 105 & 466 & 474 & 273 & 1,461 \\
Argentina & 19 & 32 & 43 & 76 & 123 & 216 & 154 & 663 \\
Brazil & 3 & 15 & 26 & 61 & 164 & 193 & 117 & 579 \\
Ecuador & 103 & 153 & 39 & 40 & 37 & 106 & 93 & 571 \\
Chile & 7 & 14 & 36 & 51 & 64 & 76 & 116 & 364 \\
Uruguay & 9 & 20 & 50 & 46 & 40 & 90 & 107 & 362 \\
Colombia & 19 & 36 & 31 & 20 & 37 & 39 & 66 & 248 \\
Romania & 7 & 25 & 15 & 28 & 64 & 73 & 17 & 229 \\
Honduras & 0 & 4 & 16 & 25 & 88 & 50 & 43 & 226 \\
Paraguay & 0 & 10 & 13 & 9 & 37 & 54 & 51 & 174 \\
Others & 20 & 30 & 46 & 81 & 148 & 221 & 114 & 660 \\
Total & 199 & 393 & 392 & 542 & 1,268 & 1,592 & 1,151 & 5,537 \\
\hline
\end{tabular}

Source: Personal correspondence with Carmen Penalba from IOM Madrid, 26 October 2010.

Tab. 5: Migration outflows from Spain, 2002-2009 (in thousands)

\begin{tabular}{lcccccccc}
\hline Year & 2002 & 2003 & 2004 & 2005 & 2006 & 2007 & 2008 & 2009 \\
Departures & 6.9 & 10 & 41.9 & 48.7 & 120.3 & 199 & 232 & 288.3 \\
\hline
\end{tabular}

Source: OECD 2011: 344.

those third country nationals who left Spain more than once throughout the year. They also included those who were expelled, some 26,000 per year throughout the 2000s (EMN 2009: 18). Moroccans were the largest group among those who were removed from Spain by force (EMN 2009: 19).

\section{$5 \quad$ Short-term versus long-term policy solutions}

\subsection{Voluntary Return Policies' strengths and weaknesses}

The Spanish VRP has its strengths and weaknesses. The major strengths of the Spanish VRP have been immediacy, administrative simplicity, budget-friendliness and openness to modification. Launched within three months of the major increase in unemployment, the programme provided delay-free return assistance to those 
migrants who were certain that they wanted to leave Spain. If a majority of Spanish immigrants decided to depart shortly after being laid off, the programme would be likely to keep unemployment pressures and anti-immigrant sentiments down. The simple design, consisting of verification of eligibility for unemployment benefits, favours fast processing of applications. Since migrants have earned their departure bonuses through social security payments, the only major cost of the programme concerns the provision of free transportation, part of which could be reimbursed to Spain from the EU's voluntary return fund.

The three-year return ban has been the programme's strength and weakness. It is likely to prevent the return of those who have not been able to integrate themselves into Spanish society. However, those few who will be under pressure to reenter Spain before the three years elapse will have to do so illegally.

Given that some of the weaknesses have already emerged, it may not be long before the Spanish VRP undergoes modification. Even though Spain implemented its very first VRP as early as 2003 , the policy has never been analysed despite the wealth of information revealed by the Western European VRPs since the late 1970s and Spain's own experience since 2003. Wishing for the VRP to provide an immediate response to the crisis, Spanish officials have also neglected to consult about the programme with the countries of origin and social actors. Both domestic and international actors would most likely have cooperated. However, they would have preferred returns to be spread out in time so as to permit all parties involved to make the necessary adjustments: namely for employers to switch to less labourintensive production; for migrants to sell any property acquired in Spain and make post-return employment and housing arrangements; for the countries of origin to prepare labour and housing markets for migrant repatriation.

The low-cost character of the Spanish VRP was also its weakness. The VRPs predating APRE run out of funds. Linked to the accumulated unemployment insurance benefits, APRE did not appeal to employed spouses of unemployed migrants, migrant children and those who have not accumulated large unemployment benefits. Furthermore, it alienated the undecided candidates, as the longer they mused over the departure decision, the smaller the departure bonuses became to which they were entitled. Most importantly, the homelands bemoaned the lack of additional funds that would allow migrants to start business at home.

When designing the programme, Spanish officials counted on the immediate departure of entire families, preferably nationals of the most impoverished countries, so as to diminish the likelihood that they would remain to work for substandard wages. However, the current programme design and the response of the countries of origin are likely to attract single returnees from relatively developed countries.

\subsection{VRPs in the context of a broader migration policy}

Thirty-five years since the first VRPs were implemented in Europe, it is still uncertain to what extent they can stimulate returns, and to what degree they can subsidise the departures of those who were going to return anyway. Having realised this challenge in the 1980s, the French invested considerable funds and efforts to 
increase migrants' incentives to repatriate. By contrast, the Dutch considered that VRPs contradicted integration policy and downplayed them. Given the low level of effectiveness of VRPs in the 1980s in terms of the proportion of migrants who returned, the programmes were phased out until they were advocated anew in the 1990s and 2000s under the assumption that they could help European countries deal with the rising entries of asylum-seekers and with irregular migration.

There is a trade-off between VRPs' costs and effectiveness. VRPs tend to be particularly costly when they aim to reintegrate migrants abroad since successful reintegration requires adequate economic, social and political stability in migrants' countries of origin and systematic post-return assistance. However, the stronger the reintegration prospects, the more likely it is that migrants will genuinely want to return home.

As implied by their name, voluntary return assistance programmes aim to be voluntary. However, few are implemented in a context in which migrants can choose between voluntary returns and other equally enticing alternatives. In a number of cases, those who avail themselves of VRPs are those who are already in an irregular status or about to enter it (e.g. rejected asylum-seekers), and their only alternative is repatriation by force. In those cases, VRPs are not genuinely voluntary and migrants are likely to avoid them or re-emigrate following their return home.

While VRPs can complement other, more complex policy measures, they cannot substitute them because VRPs are not designed to address the root causes of migration (the lack of economic, political and social stability in the countries of origin and the demand for cheap manual labour in Europe). Thus, if the countries which currently strongly promote VRPs - such as Spain - wish to bring genuine relief to migrants, their policymakers should consider implementing four measures aimed at improving the working and living conditions of those migrants who cannot return immediately. Firstly, they should facilitate labour mobility to those migrants who can earn it. Secondly, they should clarify employer duties regarding working and living conditions and verify them, to prevent that settled migrants are granted contracts on condition that they accept substandard wages or flexible schedules, lack of housing, etc. Thirdly, they should subsidise the rationalisation, mechanisation and off-shoring of production in labour-intensive sectors so that employers will reduce demand for labour as migrants move to better jobs in two or three years' time. Fourthly, they should strengthen development policies for the countries of origin to reduce emigration pressure. Whilst some of these recommendations may be easier to implement than others, they are both politically and logistically feasible as they build on the policies already implemented in most European countries, including Spain.

Since there will always be some migrants who do not want to return and who are difficult to repatriate for humanitarian or administrative reasons, they should be offered a channel through which they can earn their way to full integration in the Spanish labour market and society. One way of making VRP money more productive would be to grant the settled migrants an option to invest and create jobs in Spain. Migrant businesses created in Spain would be easier to mentor than businesses created in the countries of origin. They could benefit from much better infrastruc- 
ture and therefore would be more likely to survive. Furthermore, policies helping to promote migrants as job-givers rather than job-takers are likely to gain public support and improve migrants' integration into the Spanish society. The countries of origin would probably not oppose giving their nationals the option to invest in Spain because of their own limited reception and employment-creation capacities and the need for an uninterrupted flow of remittances. One important challenge to successful post-return development funds has been the lack of infrastructure to support investment and economic, political or social instability in the countries of origin. Investing in Spain would help to overcome these challenges even in the context of the economic crisis. However, special measures would have to be put in place so that migrant businesses do not pave the way for ethnicisation of the labour market and further expansion in the number of precarious jobs.

The less entrepreneurial foreign settlers may prefer to seek employer-dependent jobs. The economic crisis has not affected all sectors to the same extent. Even in the midst of the crisis, the unaffected sectors may find it difficult to attract Spanish workers. The Spanish government's authorisation of farmers to bring new foreign workers while repatriating those already in Spain, claiming that the repatriated individuals are unable to find jobs, is incoherent. If granted full labour mobility, many of Spain's foreign workers would most likely be willing to move to jobs which Spanish workers are not willing to take, e.g. in agriculture or domestic services. Instead of allowing those sectors to continue to recruit new workers abroad, the Spanish government should encourage them to contract with unemployed foreign workers already in Spain.

It would be unrealistic to expect foreign workers, who take the most labourintensive jobs in the context of the crisis, to want to perform these difficult tasks forever. Furthermore, it would also be unrealistic to expect the most labour-intensive jobs to survive in an economy with relatively high labour costs. But as long as migrant workers who cannot repatriate are allowed to take those jobs, they will protect themselves from unemployment and acquire the skills necessary to stay in the sector as it transforms to less-labour intensive production.

The transformation to less labour-intensive production should improve working conditions in many jobs that migrants tend to take. During the 1990s, Spanish agriculture relied heavily on migrant workers to do the jobs that even migrants themselves were abandoning as soon as opportunities in less strenuous jobs came up. As foreign worker admissions were made more difficult in the early 2000 s, and as more employers invested in labour-saving production methods, the sector adjusted to more rigorous admission rules and the employed migrants enjoyed better working conditions and incentives to stay and maintain legal status.

The Spanish government should assist the transformation from more to less labour-intensive production in order to reduce demand for jobs at the bottom of the social scale and to protect migrant workers from falling into illegality. Specifically, it could provide the financial, legal and technical support necessary for employers to rationalise, mechanise and, where necessary, engage in "offshore" production, so as to reduce demand for labour in jobs that locally-available (native or resident foreign) workers do not want to take up. 
While production "off-shoring" may seem like the most controversial and difficult to carry out in practice, it deserves consideration given that it is more likely to engage the sending and receiving countries in comprehensive cooperation than was the case with projects aimed to use migrants' savings for job creation in their homelands in the 1970s and 1980s. For example, Turkish returnees from Germany found that the sites for the new plants and the technologies to be used were often not optimum and Turkish law did not accommodate their projects. The requirement that founding capital be deposited in Turkish rather than foreign currency made entrepreneurs susceptible to inflation. Although 223 companies were functioning in the early 1980s, only 28 were operating at more than $69 \%$ capacity. With approximately 15,000 jobs created, most of the 345,000 shareholders could not expect to find employment (Rogers 1997: 161). More importantly, the wages paid for those jobs were below what most returning migrants would have found acceptable. Only a handful of companies paid dividends. By the end of the 1980s, many shares were being bought up by banks and large companies (Rogers 1997: 162).

In line with the circular migration agenda, the EU plans to open job centres in the most emigration-prone areas in Africa. It has not been clear whether such job centres would recruit workers to Europe or help workers to secure better jobs in the countries of origin. The financial crisis has slowed the expansion of foreign worker admissions to Europe. Given the controversies over whether job centres recruiting people to work in Europe would promote development in Africa or rather make Africa more dependent on jobs in Europe; one positive effect of the economic crisis may be that it will favour investment in Africa.

\section{References}

Adepoju, Aderanti; van Noorlos, Femke; Zoomers, Annelies 2010: "Europe's Migration Agreements with Migrant-Sending Countries in the Global South: A Critical Review". In: International Migration 48,3: 42-75 [doi: 10.1111/j.1468-2435.2009.00529.x].

Adler, Stephen 1976: The Organization of Return Migration: A Preliminary Analysis of the Recent Experience of France and Algeria. Document MI/76/3. Paris: OECD.

Akcayli, Nurhan 1987: Grundsätzliche Bemerkungen zu den Phänomenen von Integration bzw. Reintegration. In: Akcayli, Nurhan; Sen, Faruk (Eds.): Berufliche Integration der zweiten Türkengeneration in der Bundesrepublik Deutschland und in der Türkei. Frankfurt: Dagyeli: 16-21.

Akcayli, Nurhan; Faruk, Sen 1987: Berufliche Integration der zweiten Türkengeneration in der Bundesrepublik Deutschland und in der Türkei. Frankfurt: Dagyeli.

ATIME 2008: Informe de resultados sobre la encuesta del retorno voluntario. ATIME [http://www.atime.es/retornovoluntario.pdf].

Bastia, Tanja 2011: Should I stay or should I go? Return migration in times of crises. In: Journal of International Development 23: 583-595 [doi: 10.1002/jid.1794).

Black, Richard; Natali, Claudia; Skinner, Jessica 2005: Migration and Inequality. World Development Report 2006. Background Papers [http://siteresources.worldbank.org/ INTWDR2006/Resources/477383-1118673432908/Migration_and_Inequality.pdf]. 
Boccagni, Paolo; Lagomarsino, Francesca 2011: Migration and the Global Crisis: New Prospects for Return? The Case of Ecuadorians in Europe. In: Bulletin of Latin American Research 30: 282-297 [doi: 10.1111/j.1470-9856.2010.00494.x].

Böhning, Roger 1984: Studies in International Labor Migration. Geneva: ILO.

Castles, Stephen 2011: Migration, Crisis, and the Global Labour Market. In: Globalizations 8,3: 311-324 [doi: 10.1080/14747731.2011.576847].

Colectivo IOE 2007: Ecuatorianos en España. Una aproximación sociológica. Madrid: Ministerio de Trabajo y Asuntos Sociales [http://extranjeros.mtin.es/es/ObservatorioPermanentelntegracion/Publicaciones/archivos/ECUATORIANOS-2.pdf].

De Haas, Hein 2005: International migration, remittances and development: myths and facts. In: Third World Quarterly 26,8: 1269-1284 [doi: http://dx.doi. org/10.1080/01436590500336757].

De Haas, Hein 2007: Turning the Tide? Why Development Will Not Stop Migration? In: Development and Change 38,5: 819-841 [doi: 10.1111/j.1467-7660.2007.00435.x].

Del Barrio, Ana 2008: Los Rumanos no podrán acogerse al plan de retorno voluntario del gobierno. In: El Mundo, 19. September 2008 [http://www.elmundo.es/elmundo/2008/09/19/espana/1221814136.html].

Dobson, Janet; Latham, Alan; Salt, John 2009: On the Move? Labour Migration in Times of Recession. What Can We Learn from the Past? Policy Network Paper. London [http:// www.geog.ucl.ac.uk/research/mobility-identity-and-security/migration-researchunit/pdfs/on the move.pdf].

El Mundo 2008a: Están dispuestos los españoles a recolectar la aceituna? In: El Mundo, 4. September 2008 [http://www.elmundo.es/mundodinero/2008/09/04/econo$\mathrm{mia} / 1220518301 . \mathrm{html}]$.

El Mundo 2008b: Los inmigrantes dicen "no" al plan de Corbacho y apuestan por seguir en España. In: El Mundo, 12. October 2008 [http://www.elmundo.es/papel/2008/10/12/ espana/2518635.html].

EMN 2009: Programmes and Strategies Fostering Assisted Return and Reintegration in Third Countries. Spain. European Migration Network [http://emn.intrasoft-intl.com/ Downloads/prepareShowFiles.do?directoryID=123].

España 2009: Dictamen sobre el anteproyecto de la ley orgánica de reforma de la la ley orgánica 4/2000, de 11 enero, sobre derechos y libertades de los extranjeros en España y su integración social, modificada por las leyes orgánicas 8/2000, de 22 de diciembre, 11/2003, de 11/2003, de 29 de septiembre y 14/2003, de 20 de noviembre. Madrid: Ministerio de Trabajo y Asuntos Sociales [http://www.ces.es/servlet/noxml?id=CesColContenido\%20M01233240882765 S113938 NDic012009. pdf\&mime=application/pdf].

Ferrero-Turrión, Ruth 2010: Migration and Migrants in Spain: After the Bust. In: Papademetriou, Demetrios et al.: Migration and Immigrants Two Years after the Financial Collapse: Where do we Stand? Migration Policy Institute: Washington D.C.

France 2005: Circulaire interministérielle nDPM/ACI3/2005/423 du 19 septembre 2005 relative au programme expérimental d'aide au retour volontaire pour les étrangers en situation irrégulière [http://www.gisti.org/doc/textes/2005/circ_2005-09-19_DPMACl3-2005-423.pdf].

Gallego-Díaz, Soledad; Creamer, Daniela 2009: ¿Cuál es el problema de un eje entre Venezuela, Bolivia y Ecuador?, El País, 28 April, 2009 [http://www.elpais.com/articulo/internacional/problema/eje/Venezuela/Bolivia/Ecuador/elpepuint/20090428elpepuint_5/ Tes]. 
Gurría, Ange/ 2008: Launch of 2008 International Migration Outlook. Remarks by Angel Gurría, OECD Secretary-General. Paris, France, 10 September 2008 [http://www.oecd. org/document/26/0,3343,en_2649_201185_41292762_1_1_1_1,00.html].

Hamdouch, Bachir 2005: The remittances of Moroccan emigrants and their usage. In: OECD 2005: Migration, Remittances and Development. OECD: Paris [doi: 10.1787/9789264013896-en].

Hönekopp, Elmar 1987: Ausländische Jugendliche nach der ,Rückkehr` - wieder ein Seiteneinsteiger-Problem? In: Mitteilungen aus der Arbeitsmarkt- und Berufsforschung 20,4: 479-489.

INE 2011: Encuesta de Población Activa. Tercer Trimestre 2011. Instituto Nacional de Estadística [http://www.ine.es/daco/daco42/daco4211/epa0311.pdf].

INEM 2008: Nota informativa sobre el abono acumulado y anticipado de la prestación contributiva por desempleo a trabajadores extranjeros que retornan a su país de origen. Madrid: INEM [http://www.inem.es/inem/ciudadano/prestaciones/pdf/Nota_informativa.pdf].

INEM 2010: Demandantes de empleo, paro, contratos y prestaciones por desempleo, Ministerio de Trabajo y Asuntos Sociales. Servicio Público de Empleo Estatal. [http://www.sepe.es/contenido/estadisticas/datos_avance/datos/datos_2011/AV_ SISPE_1110.pdf].

INEM 2011: Demandantes de Empleo, Paro y Prestaciones por Desempleo. Octubre 2011. Instituto Nacional de Empleo: Madrid.

IOM 2008: Author's communication with Teresa Botella, 16 December 2008. International Organization for Migration, Madrid.

IOM 2010a: Programa de retorno voluntario de inmigratnes desde España (PREVIE). Madrid: IOM [http://www.iommadrid.es/index.php/programas-proyectos/retornovoluntario].

IOM 2010b: Programa de retorno voluntario de inmigrantes desde Cataluña (PREVICAT). Madrid: IOM [http://www.iommadrid.es/index.php/programas-proyectos/retornovoluntario]

IOM 2010c: Morocco [http://www.iom.int/jahia/Jahia/pid/406]

IOM 2010d: Phone interview with Paloma Sevillano from IOM Madrid, 18 November, 2010.

IOM 2011: Assisted Voluntary Return and Reintegration. Annual Report of Activities 2010. IOM Geneva.

Jones, Richard 1998: Remittances and inequality: a question of migration stage and geographical scale. In: Economic Geography 74,1: 8-25.

Lahlou, Mehdi 2006: Migration de retour au Maghreb, Florence: European University Institute [http://www.mirem.eu/archive/new-analytical-report-return-migration-tomorocco?set_language $=$ en].

Martin, Philip 1990: An assessment of Turkish Labor Migration to western Europe. ILO working paper. Geneva: ILO.

Marrakech Info 2008: Le Maroc appelle les pays européens à ,abandonner' la politique de retour des émigrés [http://www.emarrakech.info/Le-Maroc-appelle-les-pays-europeens-a-abandonner-la-politique-de-retour-des-emigres_a15257.html]. 
MAEC 2009: Plan d'Action. Note Synthétique Relative à la Stratégie de mobilisation en faveur de la Communauté Marocaine Résidant à l'Etranger, Rabat: Ministère des Affaires Etrangères et de la Coopération [http://www.marocainsdumonde.gov.ma/index.php?option=com_content\&task=view\&id=52\&ltemid=49]

Migrante Ecuatoriano 2009: Características del bono. SENAMI [http://www.migranteecuatoriano.gov.ec/content/view/1512/289/].

Miller, Mark 1979: Reluctant Partnership: Foreign Workers in Franco-Algerian Relations, 1962-1979. In: Journal of Interantional Affairs 33, Fall/Winter 1979.

Moffett, Matt; House, Jonathan 2010: Spanish downturn sparks immigrant exodus. In: The Wall Street Journal, 1 July, 2010 [http://online.wsj.com/article/SB10001424052748 703900004575325264137178190.html].

MTAS 2008a: El plan de retorno voluntario de trabajadores extranjeros recibe 767 solicitudes en su primer mes de vigencia [http://www.tt.mtas.es/periodico/Laboral/200812/ LAB20081213.htm].

MTAS 2008b: La Policía Nacional detiene a 77 personas por estafar más de 365.000 euros al INEM [http://www.tt.mtas.es/periodico/seguridadsocial/200903/SS20090311. htm].

MTAS 2010: Retorno Voluntario 2009-2010. Voluntary return program overview. Ministerio de Trabajo e Inmigración. Facilitated by Ma. Concepción Larre Campano, 24 November, 2010.

Muus, Philip 1988: Migration, minorities and policy in the Netherlands. Recent trends and developments. Report for the Continuous Reporting System on Migration (SOPE$\mathrm{MI})$ of the Organization for Economic Co-Operation and Development.

OECD 1983: Continuous Reporting System on Migration. SOPEMI 1982 Report. Paris: OECD.

OECD 1984: Continuous Reporting System on Migration. SOPEMI 1983 Report. Paris: OECD.

OECD 1985: Continuous Reporting System on Migration. SOPEMI 1984 Report. Paris: OECD.

OECD 1987: Continuous Reporting System on Migration. SOPEMI 1986 Report. Paris: OECD.

OECD 1988: Continuous Reporting System on Migration. SOPEMI 1987 Report. Paris: OECD.

OECD 1990: Continuous Reporting System on Migration. SOPEMI 1989 Report. Paris: OECD.

OECD 2008: International Migration Outlook 2008. Paris: OECD [doi: 10.1787/migr_ outlook-2008-en].

OECD 2011: International Migration Outlook 2011. Paris: OECD doi: 10.1596/ 9780821382189].

Ratha, Dilip; Mohapatra, Sanket; Silwal, Ani 2011: The Migration and Remittances Factbook 2011. Washington DC: World Bank [http://siteresources.worldbank.org/INTLAC/Resources/Factbook2011-Ebook.pdf]

Rogers, Rosemarie 1981: Return migration in comparative perspective. In: Kubat, Danie/ (Eds.): The Politics of Return. International Return Migration in Europe. New York: Center for Migration Studies. 
Rogers, Rosemarie 1997: Migration Return Policies and the Countries of Origin. In: Hailbronner, Kay; Martin, David; Motomura, Hiroshi (Eds.): Immigration Admissions. Vol. 3. Berghahn Books.

SENAMI 2009: Plan Retorno Voluntario: Digno y Sostenible [http://www.senami.gob.ec/ proyectos/bienvenidos-a-casa.html].

SENAMI 2011: Programa el Cucayo [http://www.migranteecuatoriano.gov.ec/content/ view/1370/211/].

SENAM/ 2012a: Facilidad para el traslado del menaje de casa y equipo del trabajo [http:// www.migranteecuatoriano.gov.ec/content/view/3018/540/].

SENAMI 2012b: Casas Ecuatorianas [http://www.migranteecuatoriano.gov.ec/content/ view/422/192/].

SEPE 2012: “¿Eres extranjera o extranjero no comunitario y quieres regresar a tu país?" [http://www.sepe.es/contenido/prestaciones/ag00d06.html\#enlace5].

Sorensen, Nina 2004: Migrant Remittances as a Development Tool: The Case of Morocco. Geneva: IOM [http://publications.iom.int/bookstore/free/Migrant_Remittances_Morocco.pdf].

Sturckow y Gonzalez, Maximo 1986: Iglesia y emigracion. In: Carta de Espana 343: 27.

Van Houte, Marieke; Davids, Tine 2008: Development and Return Migration: from policy panacea to migrant perspective sustainability. In: Third World Quarterly 29,7: 1411-1429 [doi: 10.1080/01436590802386658].

Weil, Patrick 1991: La France et ses étrangers. Gallimard.

A German translation of this reviewed and author's authorised original article by the Federal Institute for Population Research is available under the title "Die Auswirkungen von Programmen zur freiwilligen Rückkehr auf Migrationsströme im Kontext der Wirtschaftskrise 1973/74 und 2008/09" DOI 10.4232/10.CPoS-2012-03de or URN urn:nbn:de:bib-cpos-2012-03de2, at http://www.comparativepopulationstudies.de.

Date of submission: 21.08.2011

Date of Acceptance: 30.04.2012

Dr. Piotr Plewa $(\bowtie)$. International Organization for Migration. Poland.

E-Mail: pplewa@iom.int 


\section{Comparative Population Studies - Zeitschrift für Bevölkerungswissenschaft}

wWw.comparativepopulationstudies.de

ISSN: 1869-8980 (Print) - 1869-8999 (Internet)

Published by / Herausgegeben von

Prof. Dr. Norbert F. Schneider

Federal Institute for Population Research

D-65180 Wiesbaden / Germany

Managing Editor /

Verantwortlicher Redakteur

Frank Swiaczny

Editorial Assistant /

Redaktionsassistenz

Katrin Schiefer

Language \& Copy Editor (English) /

Lektorat \& Übersetzungen (englisch)

Amelie Franke

Copy Editor (German) /

Lektorat (deutsch)

Dr. Evelyn Grünheid

\section{Layout / Satz}

Beatriz Feiler-Fuchs

E-mail: cpos@destatis.de

\author{
Scientific Advisory Board / \\ Wissenschaftlicher Beirat \\ Jürgen Dorbritz (Wiesbaden) \\ Paul Gans (Mannheim) \\ Johannes Huinink (Bremen) \\ Marc Luy (Wien) \\ Clara H. Mulder (Groningen) \\ Notburga Ott (Bochum) \\ Peter Preisendörfer (Mainz)
}

\section{Board of Reviewers / Gutachterbeirat} Martin Abraham (Erlangen) Laura Bernardi (Lausanne) Hansjörg Bucher (Bonn) Claudia Diehl (Göttingen) Andreas Diekmann (Zürich) Gabriele Doblhammer-Reiter (Rostock) Henriette Engelhardt-Wölfler (Bamberg) E.-Jürgen Flöthmann (Bielefeld) Alexia Fürnkranz-Prskawetz (Wien) Beat Fux (Zürich) Joshua Goldstein (Rostock) Karsten Hank (Köln) Sonja Haug (Regensburg) Franz-Josef Kemper (Berlin) Michaela Kreyenfeld (Rostock) Aart C. Liefbroer (Den Haag) Kurt Lüscher (Konstanz) Dimiter Philipov (Wien) Tomáš Sobotka (Wien) Heike Trappe (Rostock) 